\title{
The Role of Tri Hita Karana (Thk) Culture and Business Environment toward Personality and Entrepreneurial Spirit (Study on the Members of Chambers Of Commerce in Bali Province)
}

\author{
Suana I Wayan ${ }^{1}$, Eka Afnan Troena ${ }^{2}$, Supartha Wayan Gede ${ }^{3}$, Rofiaty ${ }^{4}$ \\ ${ }^{1}$ Student of Doctorate Program, Faculty of Economics and Business, Brawijaya University, Malang, East Java, \\ Indonesia \\ ${ }^{2,4}$ Management Department, Faculty of Economics and Business, Brawijaya University, Malang, East Java, \\ Indonesia \\ ${ }^{3}$ Management Department, Faculty of Economics and Business, Udayana University, Denpasar, Bali, Indonesia
}

\begin{abstract}
This research aims to analyze the role of tri hita karana (THK) culture and business environment toward personality and entrepreneurial spirit. The total of 95 respondents is taken from business practitioners, members of chambers of commerce in Bali Province. The sample is taken by using proportional random sampling technique in the overall regencies/cities of Bali Province. The analysis utilizes path analysis. The variables of this research consist of tri hita karana (THK) culture, business environment, personality, and entrepreneurial spirit. The result demonstrates that entrepreneurial spirit is affected by tri hita karana (THK) culture, business environment, and personality. Besides, personality is influenced by tri hita karana (THK) culture and business environment. As the effort to strengthen entrepreneurial spirit, it needs personality reinforcement on the entrepreneurs, greater support of business environment, and strong and consistent implementation of tri hita karana culture by those entrepreneurs. The finding of this research is during entrepreneurial effort, entrepreneurs are required to conduct business transaction in based on the honesty as well as great support from family and government. The role of THK culture and business environment toward entrepreneurial spirit is mediated by personality variable.

Keywords: Tri Hita Karana (THK) Culture, Business Environment, Personality, Entrepreneurial Spirit
\end{abstract}

\section{Introduction}

An entrepreneur is someone who is responsible for organizing, managing, taking risk, and catching opportunity, as well as changing the opportunity into ideas that can be conducted/ marketed (Amin, 2002). There is a difference between an entrepreneur and small-business owner. Those who have entrepreneurial spirit are those who have a vision to develop their business, from small business to middle or large business; meanwhile, small-business owners are only subsistent since they only try to survive but do not have any vision to develop their business to be a greater business (Ricky and Ronald, 2007). Hermann (2011), using Big Five Personality and Meta-Analysis approaches, found significant difference between manager's and entrepreneur's personality as innovation that is implemented by individual is closely related to his/her personality. Small business practitioner that causes the business remains small is not an entrepreneur since he does not initiate innovation.

Society culture affects entrepreneurship development. Culture is values that are taken by society to where an entrepreneur lives and conduct his business. The relationship between culture and entrepreneurial spirit has been widely researched. One of the studies, conducted by Andreas et.al. (2012) mentions that culture is the key factor to be successful in developing entrepreneurial spirit.

From business environment perspective, Teixeira et.al. (2010) expressed that social network is an essential social capital which defines the growth and the success of an entrepreneurship. Miller and Gregory (1996) stated that there are five dimensions of business environment (demography, social, politic, formal law, technology, and macro economics) which must be considered to ensure the successfulness of entrepreneurship development. Other research found that entrepreneurial spirit development is affected by personality variable (study in human resource management). Avner et.al. (2006) stated that the successfulness of the students to be entrepreneurs is determined by: personality distinction, willingness to participate to business environment activities, and social participation in society. Wen (2011) mentioned that there is a strong relationship between culture which emphasizes on innovative service and pro-active personality. Besides, Christopher et.al. (2008) said that different culture causes different personality. Gordon Alport (1940) in Robbins and Judge (2009) expressed that personality is a psychological system of an individual which is adjusted to the uniqueness of the environment that he faces. Kim (2012) mentioned that a child under five years old learns from his environment 
which then shapes his personality. Therefore, it needs to conduct a research related to the role of Tri Hita Karana (THK) and Business Environment on Personality and Entrepreneurial Spirit.

\section{Review of Literature}

\subsection{Culture}

The concept of culture has emerged as the main dimension to comprehend individual behavior in an organization. There are four basic dimensions that are assumed as cultural dimensions: (1) relationship between individual and group, (2) social inequality, including relationship with the authority handler, (3) masculinity and feminism concepts, as social implication of gender difference, and (4) attitude toward uncertainty, related to the control on aggressiveness and emotional expression (Hofstede, 1994).

Sulistyawati (2000) explained Tri Hita Karana as local wisdom that has become cultural identity since it is able to accommodate and integrate external culture elements into local culture as well as become a frame life order. Tri Hita Karana is a holistic concept which includes the universe (macro-cosmos) containing physical natural environment, human as the motor of the nature, and God who animates the universe (Putra, 2000). According to Kaler (1983) in the inside part of human (micro-cosmos), THK elements consist of physical body, power or energy which activates human, and soul.

According to Susanto (2008) the implementation of THK concept in business activities is expressed in the following aspects: (1) parahyangan aspect, which means that the business managers should consider the existence of shrine (holy place for praying). At that place, human community can worship their God, (2) pawongan aspect, which means that organization management should respect individual's right among human beings, perceive all of human beings as equal one to another, and (3) palemahan aspect, which means that business management should consider both internal and external environment.

Tri Hita Karana culture is a culture which is derived from local wisdom. Susanto (2008) mentions that nation culture is shaped by some different reasons since the occurrence of a nation have different background; therefore, some factors (ethnic, economic, politic, religion, or language) provide contribution to the formation of nation culture.

\subsection{Business Environment}

Environment is not merely physical. It can be interpreted as the overall environment that is faced by an organization which can influence organization in conducting its acidities (Brooks and Weatherston, 2000). Organization environment is the complex network strength which is able to affect organization activities (Jones, 2001).

Agambisnis.Blog.com (2010) defined environment as the factors which are not controllable by an organization that can emerge opportunity or threat. The factors that influence business environment are (1) micro environment (the actors who are directly correlate with the environment which affects organization), and (3) macro environment (forces which appear and exist beyond control as usually separated from organization's operation condition).

Macro environment consists of: economic, demography, geography, technology, government, social, and political factors. Thus, it can be concluded that business environment is several aspects of life which can influence organizational activities that come from outside the organization and cannot be fully controlled by an organization. Micro environment is the core family and the big family of the entrepreneur himself or sociocultural environment (family condition); meanwhile macro environment is economic, politic, culture, law, security, technology and information, as well as global environments (Miller and Dess, 1996).

\subsection{Personality}

Feist and Feist (2006), explained that personality is a traits which is relatively permanent as well as a unique character which provides consistency and individuality toward someone's behavior. Traits contribute to the differences among individuals in their behavior. The behavior is consistent and stable in every situation.

There are some keywords that can be formulated to describe personality: way of an individual to respond particular problem, unique, dynamic, a result of physical-genetic interaction, environment, emotional, and cognition factors, showing the way of individual in managing his time.

Big five personality is an approach which is utilized in psychology to observe human personality through personality traits which consists of five personality domains constructed by using factor analysis. The fiver personality traits are: extraversion, agreeableness, conscientiousness, neuroticism, and openness to experience. Traits in the big five personality's domain of Crae and Costa (in Feist and Feist, 2006) are: (1) extraversion or also called as dominance-submissiveness; this factor is an important factor in personality, (2) agreeableness or also called as adaptability or likeability which indicates that individual is friendly, compassionate, avoid conflict, and tend to follow other people (cooperative), (3) neuroticism describes an individual who has a problem with his negative emotion such as anger, anxiety, or vulnerability, (4) openness is 
the factor which is hard to describe since this factor uses term which is not similar with the other factor. Openness refers to how a person deals to adapt to new ideas or situation. Openness has some characteristics such as tolerable, capacity to absorb information, focus and able to be aware of several emotions, thoughts, and impulsiveness, (5) conscientiousness describes an individual which is discipline, full self-control, organized, ambitious, and focus on achievement. An individual with high conscientiousness will hold discipline value and ambition; he will be a hard-worker, punctual, persistent, and sensitive to his conscience.

\subsection{Entrepreneurship}

Entrepreneurship has positive meaning as it is correlated to modern management concepts. There is a perspective which says that entrepreneurship is identical with what is possessed and done by an entrepreneur. This view is not quite correct since entrepreneurial spirit is not owned by entrepreneur only but also by anyone who thinks creatively and acts innovatively (Suryana, 2006). According to Wijardi (1988), entrepreneurship elements are divided into four parts: knowledge, skill, mental attitude, and awareness. Entrepreneurship describes an organizational behavior which includes courage to take risk, pro-activeness, and innovativeness. Entrepreneurship is an ability to create new and different thing, like creating value for himself and his surrounding (Venkataraman and Jeffery, 2010). Zimmerer and Scarborough (2008) defined entrepreneurship as a process of creativity and innovation implementation in overcoming a problem. Entrepreneur is often defines as an individual who organizes, operates, and calculates risks of a business which generates profit (Mulyadi, 2009). Furthermore, Suryana (2006) stated that entrepreneurship is creative and innovative abilities which become foundation, motivation, and source to look for opportunity to be success. The core of entrepreneurship is to create something new and different through creative and innovative thinking for making opportunity.

\subsection{Conceptual Framework}

\section{Conceptual Framework and Hypothesis}

Based on the empirical study that had been conducted, it is found that there some concepts which can be developed in this research, such as:

1) Society culture affects entrepreneur development. Culture is the values that are taken by a society to where the entrepreneur lives (or exist) to run his business. The relationship between culture and entrepreneurial spirit has been observed. Andreas et.al. (2012) conducted a research and stated that culture is the key success factor in developing entrepreneurial spirit.

2) Entrepreneurial spirit is affected by personality; and, different culture results in different personality. Hermann (2011) researched the relationship between personality and entrepreneurship by using Big Five Personality Traits approach. He found that there is a significant difference between manager's personality and entrepreneur's personality.

3) Entrepreneurial spirit is also influenced by business environment. Teixeira et.al. (2010) expressed that social network is the social capital which defines the growth and the successfulness of entrepreneur. Further, Oluremi and Gbenga (2011) mentioned that environment factor (programs implemented by government to develop entrepreneurship) has strong influence on the entrepreneurship development.

4) Culture affects personality. Wen (2011) mentioned that there is a strong relationship between culture which emphasizes on innovative service and pro-active personality. Christopher et.al. (2008) said that different culture results in different personality. Patrick et.al. 1994) stated that there is personality difference between Australian and African students.

5) Business environment influences personality. Alberto et.al. (2008) expressed that innovation success and entrepreneur's personality have very strong relationship; in addition, business environment affects innovation and personality.

Based on the inter-relationship among research variables, it leads to research conceptual framework as displayed in Fig. 3.1.

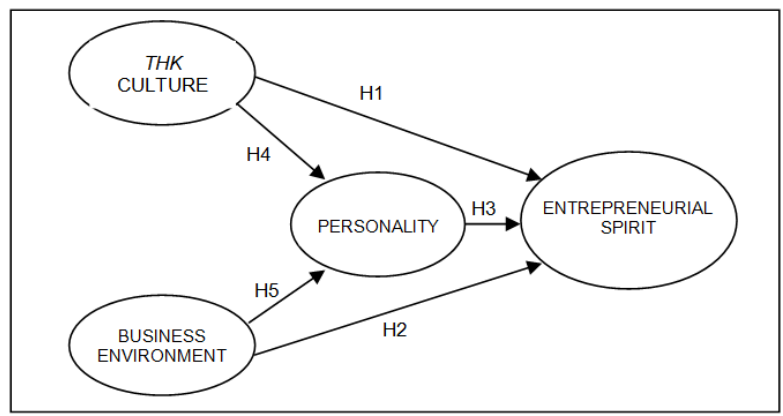

Source: Prior Research 


\subsection{Research Hypothesis}

\subsubsection{The Role of Tri Hita Karana toward entrepreneurial spirit}

Andreas et al. (2012) stated that organization behavior is the key success factor to develop product (entrepreneurial orientation. Stephan and Uhlaner (2010) said that there is a significant relationship between organization culture and entrepreneurship. Eleni et.al. (2005) mentioned that there is a strong correlation between organization culture and leader's personality as well as a strong correlation between organization culture and business transition successfulness (entrepreneurial spirit). Based on this description, it comes to the following hypothesis:

H1: $\quad$ Tri Hita Karana (THK) culture influences entrepreneurial spirit (among Chamber of Commerce's Members of Bali Province)

\subsubsection{The role of business environment toward entrepreneurial spirit}

Taragola et al. (2010) stated that government program (business environment) gives less-significant influence in developing sustainable entrepreneurship. Teixeira et.al. (2010) mentioned that social network is crucial social capital which defines growth and success of an entrepreneur. Paul and Smith (2011) said that entrepreneurial spirit is affected by individual perspective on entrepreneur profession. Oluremi and Gbenga (2011) expressed that environment factor (program conducted by government to develop entrepreneur) has strong influence in entrepreneurship development; in addition, Robert and Jintong (2011) expressed that entrepreneurship affects innovation when dynamic environment runs as its moderating variable. Based on that description, it comes to the following hypothesis:

H2: Business environment influences entrepreneurial spirit (among Chamber of Commerce's Members of Bali Province)

\subsubsection{The role of personality toward entrepreneurial spirit}

Herman (2011) said that there is a significant difference between entrepreneur's personality and manager's personality; further, he also mentioned that innovation taken by an individual has close relationship with personality. Avner et.al. (2006) wrote that the successfulness of students to be entrepreneurs is determined by personality difference, their willingness to participate in environment activities, as well as their social participation in society. In Robbins and Judge (2009), it is stated that personality has significant relationship with the type of position. An individual with particular personality should handle particular position or make particular career path to achieve successfulness. Dov Dvir et.al. (2010) said that there is a strong correlation between entrepreneur's personality and the type of business that he/she manages to achieve successfulness. From this description, it leads to the following hypothesis:

H3: Personality influences entrepreneurial spirit (among Chamber of Commerce's Members of Bali Province)

\subsubsection{The role of Tri Hita Karana culture toward personality}

Wen (2011) concluded that there is a strong relationship between culture that encourages innovative service and pro-active personality. Christopher et.al. (2008) stated that different culture may result in different personality. Wen et.al. (2008) mentioned that there is personality difference among different organizational cultures in China. Eleni et.al. (2005) said that there is a strong correlation between organizational culture and leader's personality in Cyprus. Further, Judge and Cable (1997) mentioned that there is a strong relationship between culture and student's personality in business field, engineering and industrial in The U.S. Based on the description, it comes to the following hypothesis:

H4: Tri Hita Karana (THK) culture influences personality (among Chamber of Commerce's Members of Bali Province)

\subsubsection{The role of business environment toward personality}

Kim (2012) said that birth and business environment affect individual's personality. Alberto et.al. (2008) mentioned that innovation success is determined by personality; and, entrepreneurial spirit has strong relationship with business environment. Bahattin and Muge (2010) showed that different personality and business environment in family influence student's success. Distel et.al. (2010) said that particular occurrence in an environment affects genetic and personality. Kendler et.al. (2009) concluded that family environment affects personality as genetic runs as the mediating variable. Based on the description, it leads to the following hypothesis:

H5: Business environment influences personality (among Chamber of Commerce's Members of Bali Province) 


\subsection{Sample}

\section{Method}

The number of sample is defined by using Slovin's formula (Umar, 2007). The population of Chamber of Commerce of Bali Province is 1,884 members; to adapt the $10 \%$ tolerable standard error in sampling process, the minimum number of sample taken is 95 members of Chamber of Commerce of Bali Province.

\subsection{Data collection}

This research uses both primary and secondary data. Primary data are gathered through interview based on the prepared questionnaire. Interview was conducted with 95 respondents of the Chamber of Commerce's members in all over regencies/cities in Bali Province. Secondary data are obtained through interview and taking note based on the data provided by Labor Department officers and Chamber of Commerce of Bali Province.

Research instrument utilized to collect data is questionnaire. The chosen members of Chamber of Commerce in Bali Province, as the research sample, received questionnaire. They were asked to provide their responses based on the question items. The questionnaire was tested on 30 Chamber of Commerce's members that were chosen as the respondents of this research. It is proposed to check whether they have had right comprehension on the question items in the questionnaire or not.

The answer on the statements and questions in this research is measured by using Likert's scale. Respondents are asked to state their perception by choosing one of the provided alternative answers: (5) strongly agree, (4) agree), (3) neutral, (2) disagree, and (1) strongly disagree.

\subsection{Validity and Reliability}

The validity test aims to examine how good a research instrument in measuring the concept that should be measured. The minimum requirement to fulfill the assumption is $r=0.3$. If $r<0.4$, it is not valid. The report of the calculation result on the product moment correlation is greater than 0.3 ; it is from 0.863 up to 0.998 .

The reliability test is directed to examine respondent's interpretation related to the question items in the research instrument as showed by the consistency of the provided answers. An instrument is reliable when the Cronbach's alpha coefficient is equal to or higher than 0.6 . When the reliability score is at least 0.6 , it indicates that the construct is reliable. The calculation result of the alpha coefficient on each question item is from 0.828 up to 0.997

\subsection{Analysis Method}

The analysis method utilized in this research is Path Analysis. The path model is presented in Fig.4.1

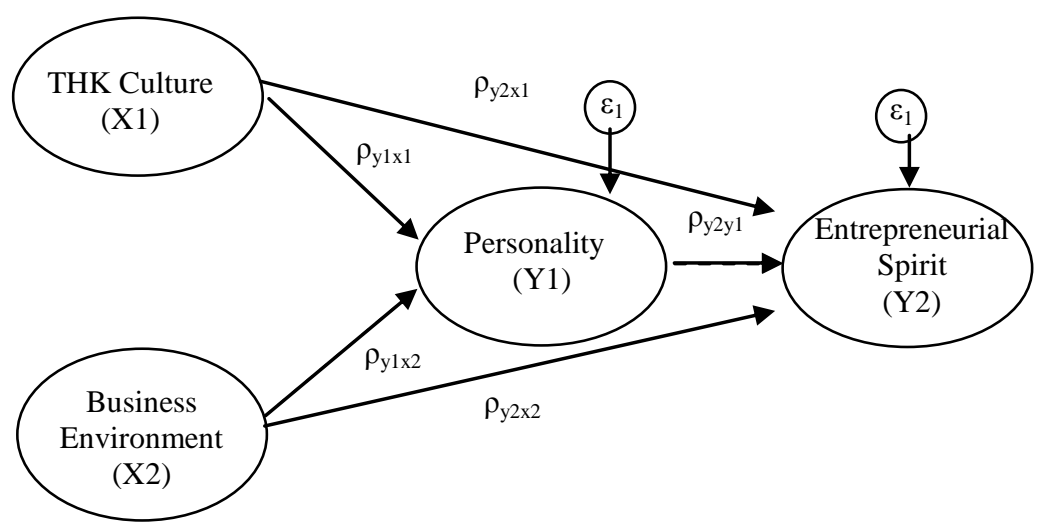

Figure 4.1. Path Model

Structural Equation: $\quad \mathrm{Y} 1=\rho_{\mathrm{y} 1 \mathrm{x} 1} \mathrm{X} 1+\rho_{\mathrm{y} 1 \times 2} \mathrm{X} 2+\rho_{\mathrm{y} 1} \varepsilon_{1}$

$$
\mathrm{Y} 2=\rho_{\mathrm{y} 2 \mathrm{y} 1} \mathrm{Y} 1+\rho_{\mathrm{y} 2 \mathrm{x} 1} \mathrm{X} 1+\rho_{\mathrm{y} 2 \mathrm{x} 2} \mathrm{X} 2+\rho_{\mathrm{y} 2 \mathrm{y} 1} \varepsilon_{2}
$$

\subsection{Respondent Characteristic}

\section{Data Analysis and Result}

Respondents, based on the gender, consist of 67 males and 28 females. The age of respondents is between 46 and 50 years old. The education level of the respondents is 34 bachelor graduates, 33 diploma graduates, and 28 middle school (senior high school) graduates. In establishing their business, there are 47 respondents who have run their business for less than 5 years, 45 respondents have run their business between 6 and 10 years, and 3 respondents who have established their business for more than 10 years. Based on business classification, small business consists of 75 respondents, middle business is 12 respondents, and large business is 8 respondents. 


\subsection{Validity and Reliability Tests}

Confirmatory factor analysis toward overall measurement items for each variable shows loading factor's score which is greater than 0.50. The extraction method which uses Principal Axis Factoring delivers Kaiser-Mayer Olkin's (KMO) score of 0.922 for THK culture, 0.904 for Business Environment, 0.794 for Personality, and 0.764 for Entrepreneurial Spirit variables. In addition, Variance Explained Total score consists of 84.824 percept for THK culture, 89.218 percent for Business Environment, 87.598 percent for Personality, and 87.625 percent for Entrepreneurial Spirit variables. The reliability test on THK culture demonstrates that Cronbach's alpha score is 0.991 , business environment is 0.990 , personality is 0.992 , and entrepreneurial spirit is 0.991 . It means that all of the variables achieve Cronbach alpha scores which are greater than 0.70 .

\subsection{Research Variable Description 1) THK Culture Description}

Based on Table 1, it reveals that, in general, the members of Chamber of Commerce in Bali Province are not yet fully implemented the values of THK culture in their business activities. Based on the average index of perception on THK culture, it can be concluded that respondent's comprehension on THK culture's values and its implementation in their business activities is categorized in to medium/ or good enough as reflected on the average index of perception which scores 2.47 .

\section{2) Business Environment Description}

Based on Table 2, it demonstrates that, in general, the members of Chamber of Commerce in Bali Province are not yet fully supported by business environment and not yet fully implemented social business activity which supports their business activities. Based on the average index of perception on business environment, the utilization of social network and business network as well as the stabilization of education and training to support business activities is categorized into medium/ good enough category as reflected on the average index of perception which scores 2.42 .

\section{3) Personality Description}

Based on Table 3, it shows that, in general, the members of Chamber of Commerce in Bali Province have relatively weak personality in conducting their business. Based on the average index of perception on personality, it concludes that respondent's personality on extraversion, agreeableness, neuroticism, openness to experience, and conscientiousness are categorized into low/ not quite good category as reflected on the average index which scores 2.35 .

\section{4) Entrepreneurial Spirit Description}

Based on the Table 4, it can be concluded that, in general, the entrepreneurial spirit of the members of Chamber of Commerce in Bali Province is not quite strong in conducting their business. Based on the average index of perception on entrepreneurial spirit, it demonstrates that the comprehension, appreciation, and implementation of the respondents on entrepreneurial spirit's dimensions are not quite strong in conducting their business. It is categorized into quite good/good enough category as reflected on the average index which scores 2.40 .

\subsection{Path Analysis Result}

As shown in Table 5, the beta coefficient of THK Culture $\left(\mathrm{X}_{1}\right)$ variable is 0.185 at 0.030 level of significance; it means that THK Culture $\left(\mathrm{X}_{1}\right)$ provides positive, significant and direct effect on personality $\left(\mathrm{Y}_{1}\right)$. The beta coefficient of Business Environment $\left(\mathrm{X}_{2}\right)$ variable is 0.787 at 0.000 level of significance; it indicates that Business Environment $\left(\mathrm{X}_{2}\right)$ has positive, significant, and direct effect on Personality $\left(\mathrm{Y}_{1}\right)$.

Based on Table 6, beta coefficient of the THK Culture $\left(\mathrm{X}_{1}\right)$ variable is 0.370 at 0.000 level of significance; it represents that that THK Culture $\left(\mathrm{X}_{1}\right)$ provides positive, significant, and direct effect on Entrepreneurial Spirit $\left(\mathrm{Y}_{2}\right)$. Business Environment $\left(\mathrm{X}_{2}\right)$ variable's beta coefficient is 0.361 at 0.005 level of significance; it implies that Business Environments $\left(\mathrm{X}_{2}\right)$ has positive, significant, and direct effect on Entrepreneurial Spirit $\left(\mathrm{Y}_{2}\right)$.The beta coefficient of Personality $\left(\mathrm{Y}_{1}\right)$ variable is 0.245 at 0.031 level of significance; it indicates that Personality $\left(\mathrm{Y}_{1}\right)$ directly, positively, and significantly affects Entrepreneurial Spirit $\left(\mathrm{Y}_{2}\right)$.

The total variance of the data can be explained by the model. It is measured by the $\mathrm{R}_{\mathrm{m}}^{2}$ as the score shows 0.993; the value of $\mathrm{R}_{\mathrm{m}}^{2}$ which shows 0.993 implies that the variance of the data can be explained by the model as many as $99.3 \%$. In other words, the $99.3 \%$ percent information contained in the data can be explained by the model; whereas, the rest $0.7 \%$ is explained by other factors which are not included in the model and due to error term. 
The path coefficient can be totally described, which explains empirical causal relationship of THK Culture $\left(\mathrm{X}_{1}\right)$ and Business Environment $\left(\mathrm{X}_{2}\right)$ toward Personality $\left(\mathrm{Y}_{1}\right)$ and its role on Entrepreneurial Spirit $\left(\mathrm{Y}_{2}\right)$ as presented in Fig.5.1.

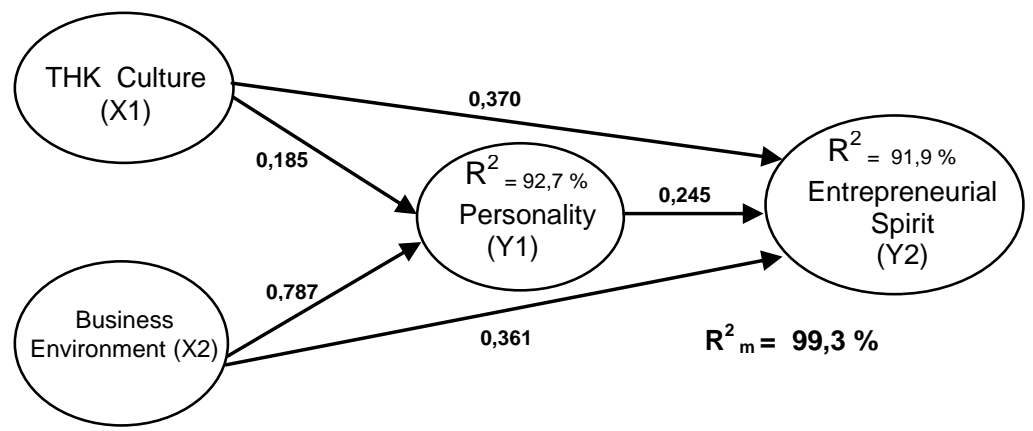

Figure 5.1. Causal Empirical Relationship between $\mathrm{X} 1$ and $\mathrm{X} 2$ toward $\mathrm{Y} 1$ and $\mathrm{Y} 2$

Based on the overall calculation, we can describe following:

(1) First hypothesis $\left(\mathrm{H}_{1}\right)$ : THK culture influences entrepreneurial spirit. From the test result, path coefficient of $\mathrm{X}_{1}$ (THK culture) toward $\mathrm{Y}_{2}$ (Entrepreneurial spirit) is 0.370 at 0.000 level of significance. Thus, the positive significant role of THK culture toward entrepreneurial spirit is confirmed.

(2) Second hypothesis $\left(\mathrm{H}_{2}\right)$ : Business environment influences entrepreneurial spirit. According to the test result, the path coefficient of $X_{2}$ variable (business environment) toward $Y_{2}$ variable (entrepreneurial spirit) is 0.361 at 0.005 level of significance. Therefore, there is positive significant role of business environment on entrepreneurial spirit.

(3) Third hypothesis $\left(\mathrm{H}_{3}\right)$ : Personality influences entrepreneurial spirit. Based on the test result, path coefficient of $Y_{1}$ variable (personality) toward $Y_{2}$ variable (entrepreneurial spirit) is 0.245 at 0.031 level of significance. Hence, in this research, it is found that the role personality on entrepreneurial spirit is positive and significant.

(4) Fourth hypothesis $\left(\mathrm{H}_{4}\right)$ : Tri Hita Karana (THK) culture influences personality. From the test result, path coefficient of $\mathrm{X}_{1}$ variable (THK culture) toward $\mathrm{Y}_{1}$ variable (personality) is 0.185 at 0.030 level of significance. It indicates that there is positive and significant role of THK culture on personality.

(5) Fifth hypothesis $\left(\mathrm{H}_{5}\right)$ : Business environment influences personality. Based on the test result, it is found that the path coefficient of $\mathrm{X}_{2}$ (business environment) toward $\mathrm{Y}_{1}$ variable (personality) is 0.787 at 0.000 level of significance. Therefore, there is positive and significant effect of business environment on personality.

\subsection{Discussion}

Referring to research result, it implies that: (1) the male members of Chamber of Commerce have stronger entrepreneurial spirit $(\mu=2.62 ; \sigma=1.441)$ than females $(\mu=1.86 ; \sigma=1.067)$. (2) the members of Chamber of Commerce who are $41-45$ years old has stronger entrepreneurial spirit $(\mu=2.65 ; \sigma=1.236)$ than any other age groups, (3) the members of Chambers of Commerce who have higher education level (bachelor graduate) has stronger entrepreneurial spirit $(\mu=3.13 ; \sigma=1,412)$ than diploma $(\mu=1.81 ; \sigma=1.211)$ and middle school graduates $(\mu=2.20 ; \sigma=1.156)$. There is a difference on entrepreneurial spirit among respondents related to the length of business establishment. The strongest entrepreneurial spirit is demonstrated by the respondents who have run their business for more than 10 years $(\mu=2.89 ; \sigma=1.540)$; whereas, the weakest entrepreneurial spirit is practiced by the respondents who have run their business between 6 and 10 years $(\mu=2.00 ; \sigma=1.128)$. There is a difference on the entrepreneurial spirit among respondents based on the business classification. The strongest entrepreneurial spirit is displayed by the respondents who have large business scale $(\mu=4.63 ; \sigma=$ $0.486)$; meanwhile, the respondents who have small business scale demonstrate the weakest entrepreneurial $\operatorname{spirit}(\mu=2.04 ; \sigma=1.269)$.

\section{1) The role of THK culture toward entrepreneurial spirit}

Referring to the score of Tri Hita Karana culture's indicators, most of the indicators are weak/less. It indicates that most of the respondents, mostly the members of Chamber of Commerce in Bali Province who manage small business have not yet implemented the values of Tri Hita Karana consistently and consequently; thus, it causes their business hard to develop becoming middle or large business. This result is relevant with other research which mentions that culture can influence entrepreneurial spirit. 


\section{2) The role of business environment toward entrepreneurial spirit}

Considering the result of the business environment's indicators, family support and government support are categorized in to weak/less; thus, it implies that family support and government support are highly needed to improve business scale from small business to middle or large business. This result is consistent with other research which confirms that business environment influences entrepreneurial spirit.

\section{3) The role of personality toward entrepreneurial spirit}

Referring to the research result of the personality variable's indicators, the indicators which construct extraversion and neuroticism are relatively low as compared to the other indicators such as agreeableness, openness to experience, and contentiousness. However, in average, the indicators which build all of the dimensions are categorized into weak/less category; thus, all of the indicators which construct personality variable should be strengthened. The research result is consistent with other research finding which mentions that personality is able to influence entrepreneurial spirit.

\section{4) The role of THK culture toward personality}

Based on the indicators that are included in parahyangan dimension which scores 55.8 to 62.1 percent, pawongan dimension which scores 56.8 to 62.1 percent, and palemahan dimension which scores 51.6 to 58.9 percent, those cause weak personality to strengthen entrepreneurial spirit. This result is supported by another research finding which concludes that culture can influence personality.

\section{5) The role of business environment toward personality}

Considering the result of the indicators included in family support dimension, those indicators score between 53.7 and 63.2 percent; social network and business network indicators reach 53.7 to 61.1 percent; formal education and training indicators score 54.7 to 58.9 percent; government support indicators achieve 53.7 to 58.9 percent. Those scores cause weak personality to strengthen entrepreneurial spirit. The result is supported by other research which confirms that business environment is able to influence personality.

\section{6) Personality variable mediates the role of THK culture toward entrepreneurial spirit}

In this research, the result demonstrates that THK culture affects entrepreneurial spirit with personality as its mediating variable. The mediation role of personality on the effect of THK culture toward entrepreneurial spirit is relatively low as compared to the direct effect of THK culture toward personality. At this case, THK culture influences personality, and then personality influences entrepreneurial spirit of the Chamber of Commerce's members in Bali Province. The relationship between THK and entrepreneurial spirit is positive. It means, in this research, that personality mediates the relationship between THK culture and entrepreneurial spirit. The relationship indicates that to strengthen entrepreneurial spirit, THK culture and personality must be strong as well so that it will result in strong entrepreneurial spirit.

\section{7) Personality variable mediates the role of business environment toward entrepreneurial spirit}

In this research, it obtains a result that business environment affects entrepreneurial spirit with personality as its mediating variable. The mediation role of personality on the role of business environment toward entrepreneurial spirit is relatively strong as compared to the direct effect of business environment on entrepreneurial spirit. Business environment influences personality; and then, personality affects entrepreneurial spirit of the Chamber of Commerce's members in Bali Province. The relationship between business environment and entrepreneurial spirit is direct and positive; the relationship between personality and entrepreneurial spirit is direct and positive as well. Thus, the relationship between business environment and entrepreneurial spirit is positive. It means that personality mediates the role of business environment variable toward entrepreneurial spirit. The relationship indicates that to strengthen entrepreneurial spirit, there should be a strong support from business environment and strong personality to achieve strong entrepreneurial spirit.

\section{Conclusion}

Based on the discussion, it concludes that: (1) THK culture variable has positive, significant, and direct effect on entrepreneurial spirit among the members of Chamber of Commerce in Bali Province, (2) business environment variable provides positive, significant, and direct effect on entrepreneurial spirit among the members of Chamber of Commerce in Bali Province; (3) personality brings positive, significant, and direct effect toward entrepreneurial spirit among the members of Chamber of Commerce in Bali Province; if the personality among the members of Chamber of Commerce in Bali Province goes weak, the entrepreneurial spirit of those members will go weak as well; (4) THK culture variable has positive, significant, and direct effect toward personality of the members of Chamber of Commerce in Bali Province; (5) business environment variable causes positive, significant, and direct effect toward personality of the members of Chamber of 
Commerce in Bali Province; (6) personality variable mediates the relationship between THK culture variable and entrepreneurial spirit variable among the members of Chamber of Commerce in Bali Province; THK culture causes positive, significant, and indirect effect on entrepreneurial spirit of the members of Chamber of Commerce in Bali Province through personality variable; (7) personality variable mediates the relationship between business environment and entrepreneurial spirit of the members of Chamber of Commerce in Bali Province; business environment has positive, significant, and indirect effect toward entrepreneurial spirit of the members of Chamber of Commerce in Bali Province through personality variable.

\section{References}

[1]. Agambisnis.Blog.com. 2010. Pengertian Lingkungan Bisnis. http://agambisnis. blog. com/ 2010/08/22/pengertian-lingkungan-bisnis

[2]. Alberto Marcati, Gianluigi Guido and Alessandro M. Peluso. 2008. The role of SME entrepreneurs' innovativeness and personality in the adoption of innovations. Original Research Article Research Policy,Volume 37, Issue 9, October, pp. 1579-1590.

[3]. Amin. 2002. Learning proximity and industrial performance: an introduction Cambrige Journal of Economic, vol. 23. Issue 3, October, pp. 239-254.

[4]. Andreas Engelen, Malte Brettel, Gregor Wiest. 2012. Cross-functional Integration and New Product Performance - The Impact of National and Corporate Culture. Journal of International Management, Volume 18, Issue 1, March 2012, pp. 52-65.

[5]. Avner Caspi, Eran Chajut, Kelly Saporta and Ruth Beyth Marom. 2006. The influence of personality on social participation in learning environments. Original Research Article Learning and Individual Differences, Volume 16, Issue 2, September, pp. $129-144$.

[6]. Bahattin, G and Muge, A. 2010. An investigation on Turkish military school students: Are there associations among big five personality factors, perceived family environment and hopelessness? Original Research Article Procedia - Social and Behavioral Sciences, Volume 2, Issue 2, August, pp. 5458-5462.

[7]. BPS Provinsi Bali. Bali Dalam Angka 2011.

[8]. Brooks Ian and Weatherston Jamie, 2000. The Business Environment. Chalanges and Changes, Second Editon. Printice Hall. San Francisco. USA. http://dx.doi.org/10.1016/0148-2963(87)90009-9.How to Cite or Link Using DOI Cited by in Scopus (31).

[9]. Christopher D. Nye, Brent W. Roberts, Gerard Saucier, Xinyue Zhou. 2008.Testing the measurement equivalence of personality adjective items across cultures. Journal of Research in Personality, Volume 42, Issue 6,December, pp. 1524-1536.

[10]. Ciputra, 2007. Pidato Pada Malam Penganugrahan Penghargaan Ernst and Young Entrepreneur of the Year 2007 di Hotel Mulia, Jakarta. Tanggal 28 Nopember.

[11]. 2009.Quantum Leap; Entrepreneurship mengubah masa depan Bangsa dan Masa depan anda. Jakarta: PT. Alex Media Komputindo.

[12]. Distel, M A; Middeldorp, C M; Trull, T J; Derom, C A; Willemsen, G. 2011. Life events and borderline personality features: the influence of gene-environment interaction and gene-environment correlation. Psychological Medicine 41. 4 (Apr): 849-60.

[13]. Donald F. Kuratko. 2009. Entrepreneurship Theory, Process, Practice. Eight Edition. South Western Cengage Learning, 5191 Natorp Boulevard Mason, OH 45040 USA.

[14]. Dov Dvir, Arik Sadeh, Ayala Malach Pines. 2010. The fit between entrepreneurs' personalities and the profile of the ventures they manage and business success: An exploratory study. Original Research Article The Journal of High Technology Management Research, Volume 21, Issue 1, p. 43-51.

[15]. Eleni T Stavrou, Tonia Kleanthous, Tassos Anastasiou. 2005. Leadership Personality and Firm Culture During Hereditary Transitions in Family Firms: Model Development and Empirical Investigation. University of Illinois at Urbana-Champaign's Academy for Entrepreneurial Leadership Historical Research Reference in Entrepreneurship.

[16]. Feist, J. \& Feist, G. J. 2006. Theories of Personality. Sixth Edition, New York; McGraw-Hill Inc.

[17]. Hermann, Brandstatter. 2011. Personality aspects of entrepreneurship: A look at five meta-analyses. Original Research ArticlePersonality and Individual Differences, Volume 51, Issue 3, August, pp. 222-230.

[18]. Hofstede, Geert. 1994. Culture and Organization, Software of the Mind. McGraw-Hill,Book Company, New York.

[19]. Jones, Garet R. 2001. Organizational Theory: Text and Cases. Third Edition. Prentice Hall. New York. USA.

[20]. Kaler I.G.K. 1983. Butir-Butir Tercecer Tentang Adat Bali. Upada Sastra. Denpasar.

[21]. Kandler, Christian; Riemann, Rainer; Kämpfe, Nicole. 2009. Genetic and Environmental Mediation Between Measures of Personality and Family Environmentin Twins Reared Together. Behavior Genetics 39. 1 (Jan): pp. 24-35.

[22]. Kasmir, 2006. Kewirausahaan. PT. Raja Grafindo Persada. Jakarta.

[23]. Kim Ian Tumblod. 2012. What Are Factors Affecting Personality. Article Source: http://EzineArticles.com/4407050

[24]. Miller Alex and Dess Gregory G.. 1996. Strategic Management. Second Edition. The McGraw-Hill Companies, Inc. New York.

[25]. Oluremi Hezekiah Abimbola and Gbenga Mayowa Agboola. 2011. Environmental Factor and Entrepreneurship Development in Nigeria. Journal of Sustainable Development in Africa. Vol. 14, No. 4. pp. 54-65.

[26]. Patrick C.L. Heaven, John Connors, Christopher R. Stones. 1994. Three or five personality dimensions? An analysis of natural language terms in two cultures. Original Research Article Personality and Individual Differences, Volume 17, Issue 2, August 1994, pp. 181-189

[27]. Paul Manimoy and Smith Hunter Andrea. 2011. Using Decision Tree Analysis to Predict Women's Entrepreneurial Choices. Academy of Information and Management Sciences Journal. Vol. 14. Issue 1 : pp. 137-162.

[28]. Putra, I.G.M. 2000. THKdalam Arsitektur Bali. Dalam Kumpulan Makalah Konsep dan Implementasi THK dalam Pembangunan Bali Menyongsong Pelaksanaan Otonomi Daerah. Pusat Kajian Bali.

[29]. Ricky W. Grifin dan Ronald J. Ebert. 2007. Bisnis. Edisi kedelapan, Erlangga, Jakarta.

[30]. Robbins, Stepen P. Timotty A. Judge, 2009, Organizational Behavior. 13 th Edition, Pearson Education, Inc., Upper Saddle River, New Jersey. Printice Hall.

[31]. Robert A. Baron, Jintong Tang . 2011. The role of entrepreneurs in firm-level innovation: Joint effects of positive affect, creativity, and environmental dynamism. Journal of Business Venturing, Volume 26, Issue 1, January 2011, pp. 49-60.

[32]. Stephan, UteView Profile; Uhlaner, Lorraine. 2010. Performance-based vs socially supportive culture: A cross-national study of descriptive norms and entrepreneurship. Journal of International Business Studies41. 8 (Oct/Nov 2010): pp.1347-1364.

[33]. Sulistyawati 2000. THK sebagai Local Genius, Kumpulan Makalah Konsep dan Implementasi THK dalam Pembangunan Bali Menyongsong Pelaksanaan Otonomi Daerah, Pusat Kajian Bali.

[34]. Suryana, 2006. Kewirausahaan: Pedoman Praktis. Kiat dan Proses Menuju Sukses. Jakarta. Salemba Empat.

[35]. Susanto A.B. 2008. Corporate Culture and Organization Culture, A Strategic Management Approach. The Jakarta Consulting Group, Jakarta. 
[36]. Taragola Nicole, Marchand Fleur, Dessein Joost, Lauwers Ludwig. 2010. Developing Indicators for Sustainable Entrepreneurship in Flemish Agriculture. European Conference on Inovation and Entrepreneueship: 602-XVIII. Reading: Academic Confrences International Limited. September.

[37]. Teixeira Rivanda Meira, Ducci, Norma Pimenta Cirilo. 2010. European Conference on Innovation and Entrepreneurship: 621-XVIII. Reading: Academic Conferences International Limited, September.

[38]. Venkataraman, S. and Jeffrey G. 2010. The entrepreneur-environment nexus: Uncertainty, innovation, and allocation Original Research

Journal of Business Venturing, Vol. 25, Issue 5, September, pp. 449-463.

[39]. Wen Dong Li, Yong-Li Wang, Paul Taylor and Kan Shi. 2008. The Influence of OrganizationalCulture on Work-Related Personality Requirement Ratings: A Multilevel Analysis. International Journal of Selection and Assessment, December. Vol. 16, Issue 4, pp. 366-384,.

[40]. Wen-Jung Chen. 2011. Innovation in hotel services: Culture and personality. International Journal of Hospitality Management, Volume 30, Issue 1, March, pp. 64-72

[41]. Zimmerer, T.W. and Scarborugh, N.M. 2008. Essential of Entrepreneurship and Small Business Management. Second Edition. Prentice Hall

Table 1.

Description on Tri Hita Karana (THK) Culture Variable

\begin{tabular}{|c|c|c|c|c|c|c|c|}
\hline \multirow{2}{*}{ No } & \multirow{2}{*}{ Dimension } & \multicolumn{5}{|c|}{ Frequency } & \multirow{2}{*}{ Mean } \\
\hline & & SD & D & $\mathbf{N}$ & $\mathbf{A}$ & SA & \\
\hline 1 & Parahyangan (X1.1) & 30 & 23 & 21 & 12 & 9 & 2.44 \\
\hline 2 & Pawongan (X1.2) & 31 & 20 & 23 & 11 & 10 & 2.46 \\
\hline 3 & Palemahan (X1.3) & 31 & 20 & 19 & 16 & 9 & 2.49 \\
\hline & Aver & $\mathrm{fe}$ & 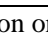 & $\mathrm{K} \mathrm{Cl}$ & $\mathrm{Va}$ & (X1) & 2.47 \\
\hline
\end{tabular}

Source: Primary Data (Appendix 8)

Table 2.

Description on Business Environment

\begin{tabular}{clcccccc}
\hline \hline \multirow{2}{*}{ No } & \multicolumn{1}{c}{ Dimension } & \multicolumn{5}{c}{ Frequency } & \multirow{2}{*}{ Mean } \\
\cline { 3 - 7 } & & SD & D & N & A & SA & \\
\hline \hline 1 & Family Support (X2.1) & 41 & 10 & 18 & 18 & 8 & 2.39 \\
2 & Social Network (X2.2) & 43 & 10 & 13 & 20 & 9 & 2.39 \\
3 & Business Network (X2.3) & 28 & 23 & 20 & 16 & 8 & 2.51 \\
4 & Formal Education and Training & 41 & 10 & 18 & 18 & 8 & 2.39 \\
& (X2.4) & & & & & & \\
5 & Government Policy (X2.5) & 41 & 10 & 15 & 20 & 9 & 2.43 \\
\hline \multicolumn{7}{c}{ Average Index of Perception on Business Environment Variable (X2) } & 2.42 \\
\hline
\end{tabular}

Source: Primary Data (Appendix 8)

Table 3.

Description on Personality Variable

\begin{tabular}{clcccccc}
\hline \hline \multirow{2}{*}{ No } & \multicolumn{1}{c}{ Dimension } & \multicolumn{5}{c}{ Frequency } & \multirow{2}{*}{ Mean } \\
\cline { 3 - 7 } & & SD & D & N & A & SA & \\
\hline \hline 1 & Extraversion (Y1.1) & 44 & 10 & 17 & 14 & 10 & 2.33 \\
2 & Agreeableness (Y1.2) & 41 & 11 & 19 & 13 & 11 & 2.39 \\
3 & Neuroticism) (Y1.3) & 41 & 10 & 20 & 14 & 10 & 2.39 \\
4 & Openness to Experience (Y1.4) & 44 & 10 & 17 & 14 & 10 & 2.33 \\
5 & Conscientiousness (X3.5) & 44 & 10 & 16 & 15 & 10 & 2.34 \\
\hline \multicolumn{4}{c}{ Average Index of Perception on Personality Variable (Y1) } & 2.35
\end{tabular}

Source: Primary Data (Appendix 8)

Table 4.

Description on Entrepreneurial Spirit Variable

\begin{tabular}{clcccccc}
\hline \hline \multirow{2}{*}{ No } & \multirow{2}{*}{ Dimension } & \multicolumn{5}{c}{ Frequency } & \multirow{2}{*}{ Mean } \\
\cline { 3 - 7 } & & SD & D & N & A & SA & \\
\hline \hline 1 & Innovative (Y2.1) & 41 & 10 & 17 & 15 & 12 & 2.44 \\
2 & Pro-active (Y2.2) & 41 & 10 & 19 & 15 & 10 & 2.40 \\
3 & Risk (Y2.3) & 44 & 10 & 15 & 16 & 10 & 2.35 \\
\hline \multicolumn{4}{c}{ Average Index of Perception on Entrepreneurial Spirit Variable (Y2) } & 2.40
\end{tabular}

Source: Primary Data (Appendix 8) 
Table 5.

Path Coefficient of THK Culture $\left(\mathrm{X}_{1}\right)$ and Business Environment $\left(\mathrm{X}_{2}\right)$ toward Personality $\left(\mathrm{Y}_{1}\right)$.

\begin{tabular}{|c|c|c|c|c|c|}
\hline $\begin{array}{c}\text { Dependent } \\
\text { Variable }\end{array}$ & Independent Variable & $\begin{array}{c}\text { Beta } \\
\text { Coefficient }\end{array}$ & t value & Sig. & Description \\
\hline \multirow{2}{*}{ Personality $\left(\mathrm{Y}_{1}\right)$} & THK Culture $\left(\mathrm{X}_{1}\right)$ & 0.185 & 2.203 & 0.030 & Significant \\
\cline { 2 - 6 } & $\begin{array}{c}\text { Business } \\
\text { Environment }\left(\mathrm{X}_{2}\right)\end{array}$ & 0.787 & 9.368 & 0.000 & Significant \\
\hline \multicolumn{4}{|c|}{$\mathrm{R}^{2}$} \\
\hline
\end{tabular}

Source: Primary Data (Appendix 8)

Table 6.

Path Coefficient of THK Culture $\left(\mathrm{X}_{1}\right)$, Business Environment $\left(\mathrm{X}_{2}\right)$, and Personality $\left(\mathrm{Y}_{1}\right)$ toward Entrepreneurial Spirit $\left(\mathrm{Y}_{2}\right)$.

\begin{tabular}{|c|c|c|c|c|c|}
\hline $\begin{array}{c}\text { Dependent } \\
\text { Variable }\end{array}$ & Independent Variable & $\begin{array}{c}\text { Beta } \\
\text { Coefficient }\end{array}$ & $\begin{array}{c}\mathrm{t} \\
\text { value }\end{array}$ & Sig. & Description \\
\hline \multirow{2}{*}{$\begin{array}{c}\text { Entrepreneurial } \\
\text { Spirit }\left(\mathrm{Y}_{2}\right)\end{array}$} & THK Culture $\left(\mathrm{X}_{1}\right)$ & 0.370 & 4.011 & 0.000 & Significant \\
\cline { 2 - 7 } & $\begin{array}{c}\text { Business } \\
\text { environment }\left(\mathrm{X}_{2}\right)\end{array}$ & 0.361 & 2.873 & 0.005 & Significant \\
\cline { 2 - 7 } & Personality $\left(\mathrm{Y}_{1}\right)$ & 0.245 & 2.194 & 0.031 & Significant \\
\hline \multicolumn{7}{|c|}{$\mathrm{R}^{2}$} \\
\hline
\end{tabular}

Source: Primary Data (Appendix 8) 